\title{
Principal Communication Management to Improve Teacher Performance
}

\author{
Herdiana 1, Yusrizal 2, Khairuddin 3 \\ DOI: 10.35445/alishlah.v13i1. 525
}

\begin{tabular}{|c|c|}
\hline Info Artikel & Abstract \\
\hline Keywords: & The purpose of this study is about the communication management of school \\
\hline Management & principals to improve teacher performance at an elementary school Banda Aceh. \\
\hline Communication & The research method used is qualitative analysis (non-statistical) according to the \\
\hline Teacher performance & aims and objectives of education research. This research is intended to develop the \\
\hline & effectiveness of the products used in schools regarding decision making by school \\
\hline & principals and to improve teacher performance which is expected to improve the \\
\hline & quality of education. The results showed that Principal communication improves \\
\hline & $\begin{array}{l}\text { teacher professionalism, conveys messages to teachers, and can carry out this } \\
\text { information. The principal as a teacher must guide all school members and carry }\end{array}$ \\
\hline & $\begin{array}{l}\text { out their duties and functions as school managers in improving the learning } \\
\text { process through classroom supervision, fostering, and providing positive } \\
\text { suggestions to teachers. }\end{array}$ \\
\hline
\end{tabular}

Kata kunci:

Manajemen

Komunikasi

Kinerja guru

\begin{abstract}
Abstrak
Tujuan dari penelitian ini adalah untuk mengetahui implementasi manajemen komunikasi Kepala Sekolah dalam meningkatkan kinerja guru. Metode penelitian yang digunakan adalah analisis kualitatif (non statistik) sesuai tujuan dan maksud penelitian di bidang pendidikan. Hasil penelitian menunjukkan bahwa komunikasi kepala sekolah dalam meningkatkan profesional guru yaitu dengan menyampaikan pesan kepada guru dan guru dapat melaksanakan informasi itu kepada anak didik. Kepala sekolah sebagai guru harus mampu memberikan bimbingan kepada semua warga sekolah dan mampu melakukan tugas dan fungsinya sebagai manajer sekolah dalam meningkatkan proses pembelajaran melalui supervisi kelas, membina dan memberikan saran positif kepada guru.
\end{abstract}

\footnotetext{
${ }^{1}$ Universitas Syiah Kuala,Banda Aceh, Indonesia

Email: Herd1anadi4n1982@gmail.com

${ }^{2}$ Universitas Syiah Kuala,Banda Aceh, Indonesia

Email: yusrizal fkip@unsyiah.ac.id

${ }^{3}$ Universitas Syiah Kuala,Banda Aceh, Indonesia

Email: khairuddin@unsyiah.ac.id
} 


\section{INTRODUCTION}

Communication activities are an essential requirement for humans to interact. It means that through communication activities, humans can mutually express their feelings and curiosity by interacting with each other. Ruliana (2016: 213) states that communication has an essential role in organizational life, including school organizations. Intensive communication interaction between school principals, teachers, employees, and students is fundamental to do. Therefore, a principal can carry out value transformation and knowledge transformation for teachers or educators. Including interpersonal communication, the principal can motivate/encourage teachers or employees to improve their work performance.

An educational institution has a principal, personnel, education supervisors, teachers, and even pupils in education. A school principal has full power over the progress of the school he leads. As a principal who carries out a management job, of course, he has a considerable influence on his subordinates. The principal must have a good character that can be used as an example in the school environment. One of them must be humble or straightforward, patient or emotionally stable, confident, honest, and skilled in his position. The principal must be a role model for his employees/teacher councils regarding good behavior, discipline, and the academic field. Also, in terms of discipline, the principal can convey rules by communication.

Indriayu (2015: 684-693) states that the principle carries out the leadership role. School leadership means influencing all personnel who support the implementation of learning activities to achieve educational goals. One of the key factors to the success of a school is the school leader (principal). In this leader's hands, the school becomes successful, superior, and even destroyed. Therefore, a principal must carry out his leadership effectively to influence his subordinates.

Communication that occurs in schools, especially between the principal and the teacher, and all subordinates, if appropriately done and intensively, will affect the attitude of the teacher in carrying out his daily duties, which leads to an increase in his performance at school. Conversely, if the communication interaction process in school is not good, it will give birth to an apathetic attitude, especially when there are differences of opinion or conflict. If that happens, it can have an impact on work results that are not optimal. Good communication is needed for the principal as the director and the staff and the teacher as the object of the direction given by the principal in the form of communication. The communication carried out by the principal takes place in the form of a reciprocal exchange of information that can be understood collective so that cooperation and creating good

Teacher performance is crucial. Teacher performance is critical to be considered and evaluated because the teacher carries out professional duties, meaning tasks that can only be done with particular competencies obtained through educational programs. One of the factors that affect teacher performance is the communication that exists between the principal and the teacher. A teacher who is not flexible in conveying material to students in the classroom due to poor communication when communicating with students also does not understand the teacher's material when learning. Likewise, with parents, parents always fail in advising their children. This is because of the lack of good communication between the parents and their children. Likewise, school principals who want to be successful in fostering and developing schools must have good communication skills in directing and guiding staff and teachers in educational institutions.

Public Elementary School 21 is a beach school where this school became a favourite of some student guardians. There are several work programs designed by this school, aiming to prepare the best graduates, develop a professional attitude, and continue to a superior school. However, based on observations in the field, it can be seen that the teacher's performance is still not optimal in carrying out their duties. There are still teachers who often arrive late without prior notification or due to the absence of a teaching schedule at the first hour, teachers who leave the classroom before the teaching and learning process is complete, even teachers who do not enter without permission. In addition, it was also found that the principal's communication was only established with certain teachers. 
These factors can be concluded that interpersonal communication between principals and teachers is not going well because of a lack of harmony and openness in communication. It can be seen from the lack of frequency of meetings in both formal and non-formal forums. One of the ways that can be taken to overcome these problems is to carry out intensive communication management. Implementation of good communication by the principal will improve teacher performance. The role of the principal as a communicator is expected to be able to coordinate all teachers or subordinates and responsibilities so that it will support the improvement of teacher performance.

Several studies have conducted about principal communication management. Tatang et al. (2015: 14) found the crucial factors contained in leadership that affect the success of a leader in activities that can support the success of his leadership are: utilization of influence, human relations, communication processes, and goal achievement. In addition, the success of a leader also depends on his competence (hard skills and soft skills), namely: the ability to influence others so that other people are willing to carry out the work planned to achieve goals and managerial abilities that emphasize things that are implementation. The importance of school principal leadership is emphasized concerning regional autonomy and education decentralization policies. In education decentralization that emphasizes school-based management, leadership (school principal) has two significant roles in carrying out its duties, first as a leader and second as a manager. Leaders act to help others in an organization with the abilities they have to achieve goals. Saefullah (2012; 139), Aedi (2015: 106) found leadership is the art and skills of people using their power to influence others to carry out certain activities directed at the goals. Therefore, leadership can be interpreted as an activity to influence people who are directed towards achieving goals. Anjaswari (2016: 127), Mutialela (2017: 227) found that communication is a similarity in the same meaning, if there are two people involved in communication, for example, in the form of a conversation, then communication will occur or last as long as there is a similarity in meaning about what is being said.

This study focus on the implementation of Principal communication management to improve teacher performance. Communication is born because of the interaction carried out by at least two people. The two parties then share information to meet their individual needs. With the fulfilment of those needs, humans can maintain their survival so that his life develops over time. Therefore, it can be said that communication is an interaction or relationship that one makes to other people to meet their needs. Therefore, management communication in the education field is an essential part of increasing the education process quality.

\section{METHODS}

This is qualitative analysis (non-statistical) according to the aims and objectives of education research. This research is intended to develop the effectiveness of products used in schools regarding school principals' decision-making and improve teacher performance, which is expected to improve the quality of education. According to Sugiono (2017: 127), a qualitative approach is a research that intends to understand the phenomena of what is experienced by research subjects. For example, behaviour, perception, motivation, action, and holistically. This research is conducted in natural conditions (as opposed to experimental) directly to the data source and the researcher as the vital instrument. In this research, qualitative research is more descriptive. The data collected is in the form of words or pictures. It does not emphasize numbers. This use qualitative research performs inductive data analysis. Several tools are used to support this research: the interview guide used as a guide for conducting interviews with relevant sources regarding this research study; the observation sheet is used to collect data and information about this research study.

The study takes place at SDN 21 Banda Aceh located on Sultan Iskandar Muda street, Lambung, Kec. Meuraxa. This research will take place between March and April 2021. There are six respondents, namely, vice-principal, teacher, supervisor, and librarian. The following activities are included: 1) administration of the research, 2) field observations and interviews, and 3) data processing and reporting. Numerous tools are utilized to assist with this research, including the following: The interview guide was used to guide interviews with pertinent sources for this research. The observation 
sheet is used to record data and information about the study. Data collection techniques used in this research are interviews, observation, and documentation. The analysis technique used in this research is a qualitative descriptive technique carried out by collecting data in depth through interviews, observation, and documentation, then analyzing the data until the report preparation process. Thus, data analysis in qualitative research is carried out during the data collection process and after completing data collection at a particular time.

\section{FINDINGS AND DISCUSSION}

Through an interview with CWN, one of the teachers at the school where the research was conducted, the researcher obtained information that the principal's communication with the teachers and staff at the school was as follows: The principal uses wise language and can control emotions. Teachers and staff who are frequently reprimanded will be given a warning level, and an agreement is made not to repeat the same mistakes. Work meetings are held once a month, and if there are considered important things, the principal will immediately communicate them in their daily lives. Warnings to teachers are usually carried out directly by the principal. There are also vice principals, for example, regarding learning in the classroom and monitoring the activities of teachers or students when the principal cannot come to school. This finding is in line with Arni's opinion (2017), which says that in leading, one must master very urgent elements, namely: 1) Deliberation, 2) Courage in truth, and 3) Optimism. Ineffective and inefficient communication will also cause inefficient work. It will cause new problems that are not controlled by the problem. In communicating in an organization, there will be an interaction between the delivery of the message and the recipient of the message, where the communicator conveys messages in the form of tasks. However, the communicant is not sensitive to the message conveyed. It will cause new problems.

For schools to develop and progress as expected, effective communication is needed, so that teacher performance increases, especially in carrying out learning activities. The researcher found information through interviews with teachers in Religious Studies, Ms MQ, who stated that principals' role in improving teacher performance was carried out through motivation and socialization of the 2013 curriculum. Student character. This is also in line with the goals and missions of the Banda Aceh city government, which is to create a brilliant generation, has good character. Principals make this happen by improving teacher performance. Information from this government program is conveyed to teachers through scheduled work meetings. Work meetings in the school environment also discuss the scope of school culture development, including harmonious relationships, communication, psychological security, physical security, collaboration, participation, and social friendliness. In line with Suranto's (2018) view, the leader must be able to 1) Express thoughts, views and opinions, 2) Share information, 3) Express feelings and emotions, and 4) Coordinate. For the organization's goals to be achieved optimally, the synergy between organizational actors can be managed, organized, and integrated with a harmonious rhythm of cooperation. The success of the principal's task in carrying out this role greatly depends on the strength of his leadership, including the communication carried out earlier. Regarding things conveyed by a leader, they must have and master communication skills to achieve the desired goals.

The principal's relationship and communication with the teachers are not only limited to scheduled meetings. Nevertheless, communication relationships are formed based on kinship that must help each other. It can be seen in the meeting results, which illustrates that the principal has long prepared an agenda for the future to make it easier for teachers. Besides that, based on the information obtained, the principal also provides opportunities for his teachers, and the principal provides additional consumption during meetings and cooperation.

Implementation of Management Communication between the principal and the supervisor is also very good. The school supervisor is a school committee responsible for advancing and improving teachers' performance to be better. The school supervisor is considered a very important figure in bridging the communication between the principal and the teacher council staff at SD Negeri 21 Banda 
Aceh. The researcher found information about the communication made by the principal with the teacher council and staff. Based on the results of interviews with supervisors, it can be seen that the principal's communication skills in influencing his subordinates are carried out well. Syafaruddin (2016: 219) states that the target of supervision is the policies and strategies that have been set and implemented under the spirit and spirit of the policies and strategies, the members of the organization are oriented to the survival and progress of the organization as a whole and not to the real interests of individuals in the area. Under the organisation's interests, the work's quality standards are met to the maximum extent possible.

Based on the findings that have been obtained from the results of interviews, observations, and also the document study conducted, several conclusions can be drawn related to the implementation of principal communication management to improve teacher performance at SD Negeri 21 Banda Aceh, namely:

1. Implementation of principal communication management to improve teacher performance at SD Negeri 21 Banda Aceh is carried out through formal and non-formal activities, both communication with staff, teachers and school supervisors based on situations and conditions.

2. Implementation of principal communication management to improve teacher performance at SD Negeri 21 Banda Aceh is carried out in official activities in routine activities carried out and informal activities that school principals often carry out daily.

3. Implementation of principal communication management to improve teacher performance at SD Negeri 21 Banda Aceh uses verbal (direct) communication between the principal and the teacher council, the principal with staff, and the principal with the school supervisor. So that with the implementation of direct communication, it is hoped that all problems or gaps that occur between superiors and subordinates can be resolved with the communication carried out.

\section{CONCLUSION}

Principal communication in improving teacher professionalism conveys messages to teachers, and teachers can carry out this information to students. The principal as a teacher must guide all school members and carry out their duties and functions as school managers in improving the learning process through classroom supervision, fostering, and providing positive suggestions to teachers. The duties of professional teachers, namely being able to carry out: curriculum administration duties and their development, management of students, personnel, facilities and infrastructure, finance, special services, and school-community relations. The principal's communication in improving teacher discipline leads to activities to educate teachers to comply with school rules by calling the person concerned personally to be advised not to harm other teachers and is invited to improve discipline. The principal's form of communication is communicating from heart to heart in certain moments and places and conducting weekly meetings. Meanwhile, the form of teacher discipline expected by the principal is punctual attendance, teaching according to lesson planning, and compiling learning tools. Principal communication in increasing teacher responsibility includes interpersonal communication and communication in solving problems that may arise in learning to improve student learning achievement. Teacher responsibility in learning includes: as a teacher, supervisor, class administrator, curriculum development, professional development and fostering community relations. Teachers are also responsible for all attitudes, behaviour, practices of students, responsibility for themselves, their colleagues, school principals, parents of students, and others.

\section{REFERENCES}

Hilman Firmansyah dan Acep Syamsudin.(2016). Organisasi dan Manajemen Bisnis. Ombak, Yogyakarta

Syafaruddin. (2015). Manajemen Organisasi Pendidikan: Perspektif Sains dan Islam. Medan: Perdana Publishing

Sinambela. Lijan Poltak. (2016). Manajemen Sumber Daya Manusia: Membangun Tim Kerja yang Solid untuk MeningkatkaSn Kinerja, Jakarta: Bumi Aksara.

Wibowo. (2016). Manajemen kinerja. Jakarta: Rajawali Pers 
Ngalimun. (2017). Ilmu Komunikasi Sebuah Pengantar Praktis. Yogyakarta: Pustaka Baru Press. Nurudin. (2016). Ilmu Komunikasi Ilmiah dan Populer. Jakarta: PT. RajaGrafindo Persada, hal. 8 Budianto, (2017). Ilmu Komunikasi, sekarang dan tentang masa depan, Jakarta. Karisma PutraUtama Syafarudin. (2016). Manajemen Organisasi Pendidikan.Bandung, Perdana Publishing Hardiansyah. (2016). Komunikasi pelayanan Publik konsep dan aplikasi. Jogjakarta: Gava Media Liliweri. (2016).Sosiologi dan Komunikasi Organisasi, Jakarta: PT Bumi Aksara

Harapan, Edi (2016). Komunikasi Antar Pribadi, prilaku insani dalam Organisasi pendidikan, Jakarta. Rajawali

Romli, Khomsahrial.(2016). Komunikasi Organisasi, Edisi Revisi. Jakarta: PT Grasindo.

Ali,Irfan,. (2016). Pola Komunikasi Organisasi forum Leader pada Aktivitas Evaluasi Bandung Clean Action. Jurnal Ilmu Komunikasi. Vol. 2(2)

Lumentut, Gracia Febrina, et al. (2017). Pola Komunikasi Pemimpin organisasi dalam meningktakna Motivasi bkerja anggota di Lembaga Pers Mahasiswa Inovasi Unsrat. Acta Diurna: 6(1)

Mulyana, Deddy. (2016). Ilmu Komunikasi Suatu Pengantar, Bandung: PT Remaja Rosdakarya.

Handayani, M. (2016). Peran Komunikasi Antar Pribadi dalam Keluarga untuk meningkatkan menumbuhkan karakter anak. Jurnal Ilmiah Visi PPTK

Suranto, AW 2015 Journal. Implementasi Komunikasi Sosial Budaya dalam Membangun Integrasi Bangsa volume 45

Cangara,Hafied 2015, Pengantar Ilmu Komunikasi, Rajawali Pers

Laksana, Muhibudin Wijaya 2015 Psikologi Komunikasi: Membangun Komunikasi yang efektif dalam interaksi manusia. Bandung: Pustaka setia

Yodiq, Muhammad. (2016). Peran Komunikasi Interpersonal Kelapa sekolah terhadap motivasi kerja Guru, e. journal Ilmu Komunikasi. Vol. 4 (1)

Hasibuan, Malayu S.P. (2016). Manajemen Sumber Daya Manusia. Edisi Revisi. Jakarta Penerbit PT Bumi Aksara

Abdullah, I., Omar, R., \& Panatik, S. A. (2016). A literature review on personality, creativity and innovative behaviour. International Review of Management Marketing, 6, 1, 177-182A

Indriayu, D. K. (2015). Kepemimpinan pembelajaran Kepala Sekolah Untuk Meningkatkan Profesionalitasme Guru Menghadapi Masyarakat Ekonomi ASEAN. Prosiding Seminar Nasional, 684-693 